$\square$ Proceedings of the Second Annual Forestry Symposium 1996: Management and Sustainable Utilization of Forest Resources, Sri Lanka, 6-7 December 1996. (Eds. Amarasekera, HS, Ranasinghe, D MSHK and Finlayson, $W$. Published by Department of Forestry and Environmental Science, University of Sri Jayewardenepura, SriLanka (1998)

\title{
ECOLOGICAL ASSESSMENT OF THE KANNELIYA DEDIYAGALA-NAKIYADENIYA (KDN) FOREST COMPLEX
}

\author{
B.M.P. Singhakumara \\ Department of Forestry and Environmental Science, \\ University of Sri Javewardenapura.
}

\begin{abstract}
A plant-ecological survey of the complex was carried out in November 1993 to Jamuary 1994. It is concluded that the Kanneliya reserve should be made a totally protected area, with buffer zones included within the present boundaries. and the other two reserves put under sustained management for multiple uses. In terms of endemism, number of species, hydrological importance, etc, Nanneliya is found to be second on. Sri Lanka only to Sinharaja in its conservation interest.
\end{abstract}

\section{Introduction}

The Kanneliya Forest Reserve (6(24.5 ha) and the Nakiyadeniya Proposed Reserve (2235.5 ha) in Galle District. and the Dediyagala Forest Reserve (3790 ha) in Matara District form a continuous block of 12.050 ha of natural forest in the southwest lowland hills, commonly referred to as the KDN forest complex.

The complex was logged by the Ceylon Plywood Corporation from 1968 until logging was suspended in 1988. The present survey showed that logging had cxtended throughout the whole area, including ridge tops and slopes of more than $30^{\circ}$. Different phases of the forest growth cycle - gaps, building, and mature forest - can be observed in various parts of the reserves. A characteristic tree colonizing heavily exploited and degraded areas is the naturalized exolic Alstonia macrophylla (hawari nuga). It is one of the pioneers (light demanders) which establishes itself in the large gaps in the wetzone forests that are creatcd by heavy logging. Advance growth of the canopy species is also found in most of the moderately-logged areas of the forest reserve.

The forest inventory that was carried out between 1982 and 1985, with the assistance of FAO. for the preparation of the Forestry Master Plan, identified 119,000) ha of closed tropical forest in the lowland wet zone as being suitable for sustainable management for timber production. These forests have high genetic, species, and habitat or ecosystem diversity and contain most of the endemic flora and fauna of the island. The proposal to exploit timber from these reserves was criticized by scientists and conservationists. As a result, the Sri Lanka government requested the International Union for Conservation of Nature (IUCN) to assess the impact of the proposed forestry operations and to develop a 
conservation strategy for the forest reserves, as well as a monitoring system for assessing changes in biodiversity (Gunatilleke \& Gunatilleke. 1990).

Under the Accelerated Conservation Review conducted in 1991, the biological and hydrological value of 31 forest reserves in Kalutara, Ratnapura, Galle and Matara Districts was evaluated. and 13 of them were identified as conservation forests. The National Conservation Review. which started in 1992. will evaluate all forest reserves in the island.

The main objective of the ecological assessment of the KDN forests reported here was to identify for conservation the ecologically critical areas, and core areas within these critical areas. taking note of biodiversity. endemism. and hydrological importance. A conservation management plan will be prepared for the parts of the complex that are designated as totally protected areas (TPAs).

Site

\section{Site and methodology}

The KDN complex forms a compact unit in the south-western conner of the wet zone between $60^{\circ}(1)^{\prime}$ and $60^{\circ} 18^{\prime} \mathrm{N}$, and $80^{\circ} 19^{\prime}$ and $80^{\circ} 27^{\prime}$ E. The mean elcvation is about $185 \mathrm{~m}$, varying from 60 to $425 \mathrm{~m}$. The Kanneliva Forest Reserve consists of several parallel ridges and valleys aligned northwest- southeast. The ridges in Nakiyadeniya and Dediyagala are lower and often broken into isolated rounded hills. all rising to about $230 \mathrm{~m}$ (Nisbet, 1961).

The Kanncliya Forest Reserve receives more rainfall (about $4445 \mathrm{~mm}$ annually) than Dediyagala or Nakiyadeniya $(3750 \mathrm{~mm})$. This difference is mainly due to aspect and relief. The south-west corner of Dediyagala forest receives only about $3125 \mathrm{~mm}$ (Nisbet 1961).

De Rosayro (1942) showed that there are four plant communities in the KDN forests. The complex was exploited. although not very intensively. at the beginning of this century. In the 1920s it was enumerated with a view to the proper management of the forest reserves. From 1950), there was controlled exploitation, by coupes managed under the selection system. However, administrative and other difficulties led to "high grading" and illegal felling (Nisbet, 1961). Even before 1961, therefore, there were large areas of advanced secondary forests in the complex.

\section{Methodology}

A review was made of the floristic and faunal (biodiversity), soil-conservation and hydrology assessment of the KDN forests by the NCR (NCR, 1992). According to the NCR data. the whole of the complex can be considered as a biologically and hydrologically critical area. 
A new hydrological assessment was made by the present survey, according to the method developed by the NCR (NCR Report 1992, Part B).

The assessment of biological diversity (in this case species diversity) of KDN forests by the NCR was made by the enumeration of only four transects. The data were collected by the Enviromnental Management Division of the Forest Department. A more detailed enumeration was carried out for the present study, to find core areas with high endemism and species riclness in the complex. The sampling of vegetation aimed at being representative of forest stands in the valleys, on mid-slopes, on ridgc-tops, and on other sites. The base map used was the 1:25,000 map prepared by the Forest Department from aerial photographs taken in 1983, which demarcated various stand types. The cover types within a stand were identified by a visual reconnaissance survey and sample plots were laid out in each type.

The fixed-area method was used for sampling because it yields data such as a species list, and estimates of stem density, frequency, diameter-class distribution, basal area. and abundance (Wenger, 1984). Several sizes of plots were laid out at each sampling location:

For trees: $500 \mathrm{~m}^{2}(0.05 \mathrm{ha}$, horizontal radius $12.6 \mathrm{~m})$

For saplings: $25 \mathrm{~m}^{2}(0.0025$ ha, horizontal radius $2.82 \mathrm{ml})$

For seedlings: $1 \mathrm{~m}^{2}(0.0001$ ha, horizontal radius $56.4 \mathrm{~cm})$

The following definitions of different habits were used:

Tree: A woody plant with a dbh greater than $10 \mathrm{~cm}$.

Sapling: A woody plant of either a shrub or tree species with a dbh less than $10 \mathrm{~cm}$, more than $1 \mathrm{~m}$ tall.

Seedling: A woody plant of either a shrub or tree species, less than $1 \mathrm{~m}$ tall.

The following parameters were recorded:

For trees: species and dbh

For saplings: species and number of stems

For seedlings: species and number of individuals

Herbarium specimens were prepared from each tree newly encountered in the samples and also along the way to the plots. General collections were also made in the surrounding area of the plots and on some transects through the reserves. In addition to the terrestrial flowering plants, epiphytes, parasites, lianes, ferns, bryophytes and lichens were collected. Most of the plants were identified by comparing them with the specimens at the National Herbarium, Royal Botanic Gardens, Peradeniya and by using the keys and information given in Dassanayake \& Fosberg (1980-1991), Mabberley (1989), Jaye-weera (1981-1982); Abeyawickrama (1978); Sri Lanka Forester (1874). Fonseka \& Vinasithamby (1971), Abeyawickrama (1959), Worthington (1959), and Senaratne (1956). 
The data on species, family, local name, dbh, height. serial numers of herbarium specimens, endemicity, ecological status, economic importance, altitude, etc. were recorded in a dBase program. Programs were written for the calculation of stand variables, diversity indices, and IVI values, for species, genera, and families. An annotated checklist has also been prepared.

Maps were prepared to show the catchment boundaries within the KDN forests, stand or cover types. plant communities, topography, infrastructure, and designated conservation zones.

Stand tables were prepared showing the distribution of diameter classes for stems greater than $10 \mathrm{~cm}$ dbh. These reveal the extent of past logging.

The reserves have been assessed for soil conservation and hydrology by the methods developed by the NCR (IUCN/EMI Report No. 14).

Ecological indices were calculated for each plot by the following formulae:

Diversity: $\quad H^{\prime}=-S p_{i} \times \log \left(p_{i}\right)$, where $p_{i}$ is the proportional abundance

Evenness: $\quad J^{\prime}=H^{\prime} / H^{\prime}$ max, where $H^{\prime} \max =\log s$, $s$ being the number of species present

Dominance: $\quad 1-J^{\prime}$

The importance value index (IVI) is an expression of the dominance of particular species (Curtis \& Mclntosh, 1950) in different habitats. In incorporates three measures: the relative density $(\mathrm{RD})$, relative frequency $(\mathrm{RF})$, and relative basal area $(\mathrm{RBA})$ - or relative dominance - into one index. This index attaches more importance to those species that tend toward large size and ubiquitous distribution than to those that do not. It is therefore a more accurate measure of the degree of influence that a species has on the community than any one of the measures it incorporates.

Relative density $=$ species density $/$ stand density

(where species density is the number of individuals of a species per unit area; i.e. the total number of individuals of a species divided by the area of the stand, and stand density is the number of individuals per unit area, i.e. the total number of individuals divided by the area of the stand; relative density is therefore also given by the number of individuals of a species divided by the total number of individuals of all species; it is also the same as the proportional abundance of a species).

Basal area is the cross-sectional area of the trees at $1.3 \mathrm{~m}$ height above ground ("breast height"). The total basal area is an important parameter which indicates the amount of biomass in the stand. 
Basal arca: $\quad \mathrm{g}=\pi \mathrm{d}^{2} / 4$, where $\mathrm{d}$ is the $\mathrm{dbh}$

Relative basal area: $\quad$ Total basal area of a species/total basal area of all species

Frequency: $\quad$ The number of plots in which a species is represented by at least one individual

Relative frequency: $\quad$ Frequency of one species/sum of frequencies of all species

Importance value index $=$ relative density + relative basal area + relative frequency

\section{Results}

There were 89 plots: 47 (total area 2.35 ha) in Kanneliya. 29 (1.45 ha) in Dediyagala. and 13 (0.65 ha) in Nakiyadeniya. Altogether, 3303 trees of more than $10 \mathrm{~cm}$ dbh were enumerated. More than 600 specimens were collected. The plants of all kinds belonged to 426 species, of which 319 have been identified, and 107 have not. The $31 \%$ identinied belong 10194 gencra and 75 families: 301 were found in Kanneliya. 280 in Dediyagala. and 295 in Nakiyadeniva. Of the 107 unidentified. 35 were identified only to family level, and 13 more to genus level, leaving 59 completely unknown. There were 159 identificd endemics (i.c. out of 319 species). Of the 18 endemic genera in Sri Lanka (Bandaranaike \& Sultanbawa. 1991: Mabberley. 1989). 9 were found. and one. Stemonopornis, was represented by two species (Table 1). Several species were unique to Kanneliya or Nakiyadeniya (Tables 2 and 3).

Table 1: Endemic genera

\begin{tabular}{lcc}
\hline \multicolumn{1}{c}{ Genus } & $\begin{array}{c}\text { Number of species } \\
\text { in Sri Lanka }\end{array}$ & $\begin{array}{c}\text { Number of species } \\
\text { found in KDN complex }\end{array}$ \\
\hline Hortonia & 2 & 1 \\
Leucocodon & 1 & 1 \\
Loxococctis & 1 & 1 \\
Nargedia & 1 & 1 \\
Phenicanthws & 2 & 1 \\
Schumacheria & 3 & 1 \\
Scyphestachws & 2 & 1 \\
Stenoporus & $15(26)$ & 2 \\
Schizostigma & 1 & 1 \\
\hline
\end{tabular}


Table 2 : Species unique to Kanneliya forest reserve (not recorded from the other two reserves in the course of present survey)

\begin{tabular}{|c|c|c|c|c|}
\hline \begin{tabular}{|c|} 
Species \\
\end{tabular} & Family & END & THR & RDB \\
\hline Agrostistachys hookeri & Euphorbiaccac & $\checkmark$ & & $\mathrm{V}$ \\
\hline Burmannia pusilla & Burmanniaceac & & & \\
\hline Cotylelobium scabriuscultum & Dipterocarpaceac & $\checkmark$ & $\checkmark$ & $\mathrm{E}$ \\
\hline Elastoma linoleatum & Urticaceac & & & \\
\hline Eugenia insignis & Myrtaceac & $\checkmark$ & & \\
\hline Hopea jucunda ssp. jucunda & Diptcrocarpaceac & $\checkmark$ & & $\mathrm{R}$ \\
\hline Nicrotropis wallichiana & Celastraceae & & & \\
\hline Sonerila zeylanica & Melastomataceac & $\checkmark$ & & \\
\hline t'temonoporus kanneliyansis & Dipterocarpaceae & $\checkmark$ & & \\
\hline lafica afjimis & Dipterocarpaceac & $\checkmark$ & & $E$ \\
\hline
\end{tabular}

END - endemic; THR - threatencd: RDB: Red Data Book catcgory

Table 3 : Species unique to Nakiyadeniya forest reserve (not recorded from the other two reserves in the course of present survey)

\begin{tabular}{|c|c|c|c|c|}
\hline Species & Family & END & THR & RDB \\
\hline Ficus exasperata & Moraceac & & & \\
\hline Plerospermum canescens & Stcrculiaccac & & & \\
\hline Symplocos coronata & Symplocacaceac & & & \\
\hline Lamilla moomii & Orchidaceac & $\checkmark$ & & \\
\hline
\end{tabular}

END - endemic: THR - threatened: RDB: Red Data Book category

Table 4 gives the number of endemic species. number of endemic individuals and their basal area. Table 5 summarizes these data, and ranks the three reserves according to the importance of the contribution of their endemic species. taking into account the number of species, number of individuals, and basal area.

Table 4: Sampling data (trees of more than $10 \mathrm{~cm}$ dhh)

\begin{tabular}{lccc}
\hline & Kanneliya & Dediyagala & Nakiyadeniya \\
\hline Plots & 47 & 29 & 13 \\
Species identificd & 144 & 107 & 98 \\
Endemic species & 75 & 59 & 50 \\
$\begin{array}{l}\text { Endemic species as \% of } \\
\text { identificd species }\end{array}$ & 52 & 55 & 51 \\
$\begin{array}{l}\text { Total individuals } \\
\text { Endemic individuals }\end{array}$ & 1773 & 1067 & 463 \\
$\begin{array}{l}\text { Endemic individuals as \% } \\
\text { of total cnumerated }\end{array}$ & 1126 & 370 & 278 \\
Total basal area $\left(\mathrm{m}^{2}\right)$ & 63.5 & 34.7 & 60.0 \\
$\begin{array}{l}\text { Basal area of endemics } \\
\text { (min) }\end{array}$ & 77.0 & 49.1 & 26.8 \\
Basal area of endemics as & 50.1 & 33.6 & 17.0 \\
$\%$ of total & 65.0 & & \\
\hline
\end{tabular}


Table 5: Ranking of reserves according to the contribution made by endemic tree species of more than $10 \mathrm{~cm}$ dbh (see text)

\begin{tabular}{|c|c|c|c|c|c|c|c|}
\hline & Species & $\begin{array}{c}\text { Endenuic } \\
\text { species }\end{array}$ & Individuals & $\begin{array}{c}\text { Endemic } \\
\text { individuals }\end{array}$ & Basal area & $\begin{array}{l}\text { Endemic } \\
\text { basal area }\end{array}$ & Rank \\
\hline Kanneliya & 144 & 75 & 1173 & 1126 & 77.0 & 50.1 & 1 \\
\hline Dediyagala & 107 & 59 & 1067 & 370 & 49.1 & 33.6 & 2 \\
\hline Nakiyadeniya & 98 & 50 & 463 & 278 & 26.8 & 17.0 & 3 \\
\hline
\end{tabular}

According to IUCN (1993) there are more than 30 species of threatened plants ( 24 of them endemic) among those enumerated in these reserves. This number is an underestimate because some species will not have been collected during the two months of field work, and also because some of the collected specimens have not been identified because of the absence of material for comparison in the National Herbarium.

\section{Plant rarity}

There were 144,107 , and 98 species of trees of more than $10 \mathrm{~cm}$ dbh identified in the Kanneliya, Dediyagala and Nakiyadeniya reserves, respectively. None of these species was represented in all of the sample. On the other hand, there were 49,29 and 43 species that were recorded only once, taking each reserve separately. In Kanneliya, for example, nearly a third of the species were found only once. It can be considered that these species are rare

\section{Biological diversity}

The diversity indices show that all three forest reserves have more or less similar high species diversity, except for a few plots with low diversity. The average diversity does not show any significant difference between the three reserves (Table 6).

Table 6 : Analysis of variance

\begin{tabular}{lccccc}
\hline Source & DF & SS & MS & F & P \\
\hline Factor & 2 & 0.0691 & 0.0345 & 2.09 & 0.130 \\
Error & 86 & 1.4211 & 0.0165 & & \\
Total & 88 & 1.4902 & & & \\
\hline & & & & & \\
\hline \multicolumn{1}{c}{ Level } & N & Mean & STDEV & \\
\hline Kanneliya & 47 & 1.1172 & 0.1235 & \\
Dediyagala & 29 & 1.0597 & 0.1330 & \\
Nakiyadeniya & 13 & 1.1249 & 0.1368 & \\
\hline
\end{tabular}

Evenness (or equitability) is also very high in the three forest reserves, because of the more or less equal distribution of different taxa. In diverse communities, most species are relatively rare. The lowland forest shows the least dominance, when compared with the other forest formations. Consoci-ations have therefore less chance of occurring in lowland forest formations. 
Importance value indices (IVI)

Tables 7 shows the ranking by IVI indices of the 15 most dominant families in each of the three reserves. The Clusiaceae and Dipterocarpaceae are generally the first and sccond most dominant in undisturbed lowland forests, c.g. in the Sinharaja World Heritage site (Gunatilleke \& Gunatilleke. 1985). Table 7 shows that in Kanneliya, these two families are the first and third most dominant.

Table 7 : Ranking of 15 families in each reserve by IVI

\begin{tabular}{lccc}
\hline & Kanneliya & Dediyagala & Nakiyadeniya \\
\hline Clusiaceac & 1 & 8 & 6 \\
Anacardiaccac & 2 & 2 & 4 \\
Dipterocarpaceae & 3 & 7 & 3 \\
Euphorbiaceae & 3 & 3 & 1 \\
Sapotaceae & 5 & 5 & 9 \\
Dilleniaceac & 6 & 1 & 2 \\
Anisophyllaceae & 7 & 4 & 12 \\
Bombacaccac & 8 & 14 & 11 \\
Annonaceac & 9 & 6 & 5 \\
Thymelacaceae & 10 & 9 & - \\
Rubiaceac & 11 & 10 & 8 \\
Myrtaceae & 12 & 12 & - \\
Myristicaceac & 13 & 11 & 14 \\
Mclastomataceae & 14 & - & 15 \\
Flacourtiaceac & 15 & 13 & 7 \\
Lauraceac & - & 15 & - \\
Ebenaceac & - & - & 10 \\
Moraceae & - & - & 13 \\
\hline
\end{tabular}

Table 8 compares the five most dominant families in each of the three reserves with those of Singharaja, and ranks the reserves by comparison with undisturbed forest (i.e. Singharaja).

Table 8 : Dominance of families: reserves ranked by comparison with Singharaja

\begin{tabular}{|c|c|c|c|c|c|c|}
\hline Kanneliya & Clusiaceae & Anacardiaceac & Dipterocarpaceae & Euphorbiaceae & Sapotaceae & $\begin{array}{c}\text { Rank } \\
1\end{array}$ \\
\hline Dediyagala & $\begin{array}{c}\text { Dilleniacea } \\
\mathrm{e}\end{array}$ & Anacardiaceac & Euphorbiaceate & Anisophylleaceae & Sapotaceae & $\begin{array}{c}\text { Rank } \\
3\end{array}$ \\
\hline $\begin{array}{l}\text { Vakiyadeni } \\
\text { ya }\end{array}$ & $\begin{array}{c}\text { Euphorbiac } \\
\text { cac }\end{array}$ & Dilleniaceae & Dipterocarpaceae & Anacardiaceae & Annonaceae & $\begin{array}{c}\text { Rank } \\
2\end{array}$ \\
\hline Singharaja & Clusiaceae & $\begin{array}{c}\text { Dipterocarpacea } \\
e\end{array}$ & Sapotaceae & Bombacaceae & Myrtaceae & \\
\hline
\end{tabular}

Tables 9 shows the ranking by IVI indices of the 15 most dominant genera in each of the three reserves. 
Annual Forestry Symposium, 1996

\begin{tabular}{lccc}
\hline \multicolumn{4}{c}{ Table 9: Ranking of $\mathbf{1 5}$ genera in each reserve by IVI } \\
\hline & Kanneliya & Dediyagala & Nakiyadeniya \\
\hline Shorea & 1 & 5 & 3 \\
Semecarpus & 2 & 3 & 2 \\
Palaquium & 3 & 6 & 9 \\
Dillenia & 4 & 1 & 1 \\
Anisophyllea & 5 & 2 & 13 \\
Cullenia & 6 & & 7 \\
Gyrinops & $7 \mathrm{~b}$ & 8 & \\
Garcinia & 8 & & 12 \\
Chaetocarpus & 9 & 4 & 10 \\
Syzygium & 10 & 14 & 14 \\
Calophyllum & 11 & & 4 \\
Xylopia & 12 & 7 & 6 \\
Diospyros & 13 & 13 & 15 \\
Myristica & 14 & & \\
Mesua & 15 & 9 & 11 \\
Campnosperma & & 11 & 5 \\
Mangifera & & & 8 \\
Gaertnera & & & \\
Hydnocarpus & & & \\
Mallotus & & & \\
\hline
\end{tabular}

Tables 10 shows the ranking by IVI indices of the 15 most dominant species in each of the three reserves.

Table 10 - Ranking of 15 species in each reserve by IVI

\begin{tabular}{lccc}
\hline & Kanneliya & Dediyagala & Nakiyadeniya \\
\hline Anisophyllea cinnamomoides & 1 & 1 & 11 \\
Cullenia rosayroana & 2 & & 5 \\
Gyrinops walla & 3 & 5 & \\
Dillenia retusa & 4 & 2 & 1 \\
Xylopia champonii & 5 & 4 & 12 \\
Semecarpus walkeri & 6 & 6 & \\
Palaquium canaliculatum & 7 & 12 & 10 \\
Semecarpus parvifolia & 8 & & 13 \\
Chaetocarpus castanocarpus & 9 & 3 & \\
Myristica dactyloides & 10 & 11 & \\
Garcinia echinocarpa & 11 & & \\
Dillenia triquetra & 12 & 9 & \\
Campnosperma zeylanica & 13 & 7 & \\
Shorea congestiflora & 14 & 14 & \\
Shorea megistophylla & 15 & & \\
Mangifera zeylanica & & 8 & \\
Gaertnera vaginance & & 10 & \\
\hline
\end{tabular}


Aporusa cardiosperma

13

Hydnocarpus octandra

15

\section{3}

Diospyros sp.

4

Mallotus sp.

(vathocalvx

Palaquium petiolare

Shorea worthingtonii

\section{Diameter distribution}

Table 11 shows the number of stems enumerated in the plots by three diameter classes $(10-30,30-60$, and $>60 \mathrm{~cm})$ in each reserve. These data are also converted to stems per hectare. Note in particular that the numer of stems/ha of more than $60 \mathrm{~cm}$ at Kanneliya, Dediyagala and Nakiyadeniya was only 8,10 , and 15. This gives an indication of the severity of logging. In the areas set apart for sustainable timber management there must first be a long resting period.

Table 11 : Diameter-class distribution

\begin{tabular}{|c|c|c|c|c|c|c|c|}
\hline & \multirow[t]{2}{*}{ Plots } & \multicolumn{3}{|c|}{ Total stenis } & \multicolumn{3}{|c|}{ Stems/ha } \\
\hline & & $10-30 \mathrm{~cm}$ & $30-60 \mathrm{~cm}$ & $>60 \mathrm{~cm}$ & $10-30 \mathrm{~cm}$ & $30-60 \mathrm{~cm}$ & $>60 \mathrm{~cm}$ \\
\hline Kanneliya & 17 & 1499 & 255 & 19 & 637 & 108 & 8 \\
\hline Dediyagala & 29 & 871 & 181 & 18 & 600 & 125 & 10 \\
\hline Nakiyaleniya & 13 & 392 & 61 & 10 & 603 & 94 & 15 \\
\hline
\end{tabular}

\section{Plant communities}

The IVI index was calculated for the 10 most dominant species in each plot. Note that the relative frequency, as defined above, is the same for all species, as it depends only on occurrence in the plot. It will be recalled also that "dominant" here does not refer to status in the canopy. The following is a list of the species that occur as the most dominant species in particular plots, as determined by their IVI value:

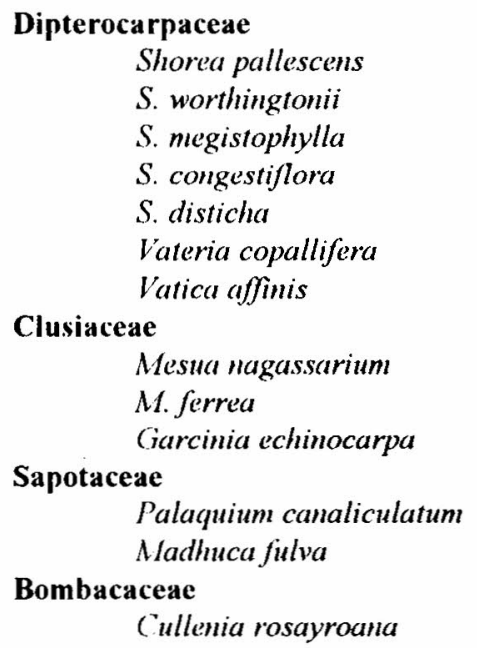


Myrtaceae

Syzygium makul

S. firmum

Anisophylleaceae

Anisophyllea cinnamomoides

Anacardiaceae

Campnosperma zeylanica

Euphorbiaceae

Senecarpus walkeri

Chaetocarpus castanocarpus

Agrostistachys hookeri

Apocynaceae

Apornsa cardiosperma

Melastomataceae

Alstonia macrophylla

Dilleniaceae

Axinandra zeylanica

Cornaceac

Dillenia retusa

Celastraceae

Mastixia tetrandra

Annonaceae

Bhesa zeylanica

(ythocalyx zeylanica

Verbenaceae

Vitex altissima

Moraceae

Ficus spp.

Several plant communities can be distinguished. De Rosayro's first two communities (Dipterocarpus and Mesua-Shorea) are present in some parts of the reserves, mixed with some secondary species. Ashton \& Gunatilicke (1987) correctly identified these as successional composite communities. The Dipterocarpus community is found close to the Dediyagala Arnaya. It is not recorded from Kanneliya or Nakiyadeniya. The MesuaShorea community is recorded from different parts of Kanneliya - mainly ridge tops. Most of the Shorea species are dominant in the valleys and on the mid-slopes in Kanneliyaa, but Mesua is not well represented. This community is more dominant in successional areas in the Kanneliya forest than it is in the other two reserves.

Alstonia macrophylla is dominant in heavily logged areas in all the reserves as a secondary (pioneer) tree species. A Dillenia-Anisophyllea-Axinandra-ChaetocarpusAporusa-Campnosperma community is found in parts of Dediyagala (plots 61-72) and Nakiyadeniya (plots 73-79) as a successional community. It is possible to identify the seedlings, saplings, and pole-size trees of primary (climax) species in the successional comnunities. It is concluded that the species composition of the community described by de Rosayro has been disturbed. 


\section{Forest structure}

Emergent trees are not found in any of the reserves. The main canopy contains species such as Shorea pallescens, $S$. worthingtonii, $S$. megistophylla, $S$ congestiflora, $S$. disticha, Vateria copallifera, Vatica affinis, Hopea spp., Calophyllum spp.. Mesua spp., Myristica dactyloides, Hydnocarpus octandra, Cullenia rosayroana, Palaquium canaliculatum, Bhesa spp., Syzygium spp., and Dipterocarpus spp.

The sub-canopy consists of Calophyllum spp., Garcinia echinocarpa, G. hermonii, Xylopia championii, Axinandra zeylanica, Semecarpus spp. Dillenia retusa, D. triquetra, Aporusa spp., Chaetocarpus spp., Cyathocalyx spp.. and Enicosanthum spp.

The understorey contains (ryptocarya wightiana, Memecylon spp., Mallotus spp., Hedyotis spp., Gyrinops walla, Timonius jambosella, Diospyros spp., Stemonoporus kanneliyensis, and S. bullatus, along with seedlings and saplings of canopy and subcanopy species.

\section{Discussion}

\section{Present status of the KDN forest complex}

'I'he investigations described above have shown that most areas of the reserves have been degraded by various degrees of disturbance. i.e. by authorized logging or illicit felling. The cemumerations found an average of only ten trees per ha of more than $60 \mathrm{~cm}$ dbh, which means that there must have been heavy logging in most of the accessible parts of the complex. The Plywood Corporation was unable to supply data on removals.

However, the forest contains more than 20,000 saplings (dbh $>10 \mathrm{~cm}$, height $>1 \mathrm{~m}$ ) and more than 600 trees of $10-30 \mathrm{~cm}$ dbh per hectare. The disturbed forest is regenerating fast. Most of the heavily logged and degraded areas are being colonized by Alstonia macrophylla, which is an exotic pioneer (light demander or secondary species) now naturalized in the wet zone of Sri Lanka. There are more or less pure stands of this species in some parts of the reserves. Seedlings. saplings and pole-size trees of climax species (shade bearers or primary species) are also established under the Alstonia macrophylla. Most pioneer tree species have a relatively short life span compared to that of climax species. All pioneer trees need full sunlight for seed germination and therefore it can be assumed that once the existing Alstonia macrophylla die off the growing space will be occupied by saplings and pole-size trees of primary species. In time these species will form a climax forest.

There are also moderately logged areas which are in difkrent phases of the forest growth cycle (gap, building, and mature phases). These areas show a mixlure of the plant species that are found in both undisturbed and secondary forests. The species recorded in de Rosayro's Dipterocarpus and Shorea-Mesua communities are found, along with those found in the other two communities of lowland rain forest, which shows that these areas are in different stages of secondary succession. 
The skidding trails and logging roads are partly covcred with kekilla fern (Dicranopteris linearis) and grasses, or by shrub species such as Schizostigma hirsuta. This cover helps to reduce soil crosion. The developing crowns of adjacent trees are causing these species to die out, but regeneration of tree species is poor because of soil compaction and the absence of litter.

There are encroachments for tea growing and human settlement along the boundaries of all the reserves. Illicit felling continues unabated, especially in Dediyagala and Nakiyadeniya. More than twenty pit saws were seen in the detached part of the Nakiyadeniya reserve.

Pcople from the surrounding villages collect various non-wood products (dummala, kokun bark. weniwel. wewel. etc.) Some kokun trees (Kokoona zeylanica) have been killed by excessive removal of bark. Dorana trees (Dipterocarpus glandulosa) have also been damaged or killed by people extracting dorana oil.

\section{Plant diversity}

The diversity indices showed no significant differences between the reserves. However. these indices only show that in numerical terms each reserve is equally diverse. They do not take account of habitat differences between the reserves. Also, they refer only to woody plants of more than $10 \mathrm{~cm}$ dbh. These limitations should be kept in mind when areas are selected for conservation. There may also be differences in hydrological importance.

The total numbers of species. endemic species, individuals. and basal areas were all greatest in Kanneliya, which contains 23 species of Dipterocarpaceae. The present survey found 10 species only in Kanneliya and 4 in Dediyagala, but most of them are recorded also in forests other than those in this survey.

The NCR covered a total of 52 forests, including the KDN complex, in and around the Southern Province. It used Gradset sampling, i.e. it took samples along the steepest environmental gradients. Table 12 sets out its results for the three KDN reserves:

Table 12 - Diversity of woody plants according to National Conservation Review

\begin{tabular}{lccccccc}
\hline & Families & Genera & Species & Unique & Endemic & \multicolumn{2}{c}{$\begin{array}{c}\text { Threatened } \\
\text { Nationally }\end{array}$} \\
& & & & & & Globally \\
\hline Kanneliyab & 147 & 149 & 233 & 2 & 140 & 26 & 16 \\
Dediyagala & 126 & 126 & 189 & 1 & 112 & 18 & 10 \\
Nakiyadeniy & 161 & 164 & 237 & 5 & 117 & 24 & 11 \\
a & & & & & & & \\
\hline
\end{tabular}

According to the NCR data, Nakiyadeniya and Kanneliya are the most diverse forests for woody plants after Sinharaja World Heritage Site (which has 277 woody species and 150 endemic woody species). The second highest number of endemic plants has been recorded from Kanneliya. The Kanneliya reserve is also notable for having the highest numbers of threatened woody plants nationally (26) and globally (16). 
For both woody plants and animals the NCR data show that the larger the size of a forest. up to a certain limit, the greater the number of species it contains. The NCR also shows that many forests contain one or more rare species that are uniquely restricted to that particular site. There is no clear relationship between the number of species unique to a particular forest and its size in the case of either plants or animals. Seventy-five "unique woody plant species" were recorded from 39 forest reserves in the wet zone during the NCR survey in 1992. However, almost all of these species have been recorded from other wet zone forests since that datc. Also, the finding of a species unique to a particular forest depends on the sampling intensity. More intensive sampling of the flora in one forest may reduce the numbers of "unique species" recorded for another reserve.

A ranking of forest complexes based on their contribution of unique species or unique endemic species to the network has been made by the NCR (1992). Ranking of forest reserves on the basis of species uniqueness is not a good method for selecting conservation areas in the wet zone, but in addition, the NCR does also take account of the forests' importance for soil conservation and hydrology.

Table 13 lists the species recorded by the NCR as unique to one forest of the KDN complex, and gives the other localities for which there are records.

Table 13: NCR's "unique" species, and other recorded localities

\begin{tabular}{|c|c|c|c|}
\hline KDN Forest & NCR (1992) & Other localities & Recorded in \\
\hline \multirow[t]{2}{*}{ Kanneliya } & Gardenia latifolia & $\begin{array}{c}\text { Colombo \& Kalutara } \\
\text { Districts }\end{array}$ & $\begin{array}{c}\text { Revised Flora Vol. } \\
\text { IV }\end{array}$ \\
\hline & Hiplage benghalensis & 7 Districts & $\begin{array}{c}\text { Revised Flora Vol. } \\
\text { VII }\end{array}$ \\
\hline Dedivagala & Madhuca moonii & Kanneliya & Present survey \\
\hline \multirow[t]{5}{*}{ Nakiyadeniya } & Ficus asperrima & Kandy District & $\begin{array}{c}\text { Revised Flora Vol. } \\
\text { III }\end{array}$ \\
\hline & Ixora thwaitesii & Maliboda & $\begin{array}{c}\text { Peak Wilderness } \\
\text { Survey }\end{array}$ \\
\hline & $\begin{array}{l}\text { Rhynchotoechum } \\
\text { permolle }\end{array}$ & 3 Districts & $\begin{array}{c}\text { Revised Flora Vol. } \\
\text { III }\end{array}$ \\
\hline & Sygygium turbinatum & Maskeliya & $\begin{array}{c}\text { Peak Wilderness } \\
\text { Survey } \\
\end{array}$ \\
\hline & Wrightia angustifolia & 8 Districts & $\begin{array}{c}\text { Revised Flora Vol. } \\
\text { IV }\end{array}$ \\
\hline
\end{tabular}

\section{Importance value indices}

The IVI values for plant families in Kanneliya show that the families dominant in undisturbed forests found in the other two reserves are well represented. This finding indicates that the floristic compo-sition of Kanneliya is still that of an undisturbed forest of the low-country wet zone. It is important therefore to designate this reserve as a 
Totally Protected Area (TPA). The natural recovery of the species composition after logging is greater in Kanneliya than in the other two reserves. It will be an area of high species diversity and endemism second only to Sinharaja.

Tropical forest ecologists believe that in Southeast Asia, those forests which have had a first cut of selective logging have not lost many plant species, so that species diversity may be the same before and after logging, while many species may be lost if a second cut takes place. However, this outcome will depend on when the second cut takes place and on what basis (Whitmore \& Sayer, 1992).

\section{Plant rarity}

Of the total number of plant species recorded from plots in each reserve, 49 species in Kanneliya were recorded only once. The corresponding numbers in Dediyagala and Nakiyadeniya were 29 and 43 . The plants represented by these numbers are obviously not distributed throughout the reserves, and for this reason it is necessary to designate large protected areas to conserve plant species which have low population densities. The animal species that pollinate and disperse the fruits and seeds of these plant species may also show a patchy distribution.

The present ecological assessment does not allow an assessment to be made of the size of the populations of particular plant species. The number of individuals of a plant species may have been reduced as a result of logging. The population sizes of most tropical plant species are unknown. Many exist as small populations of 500, 100, or even fewer individuals, either from natural causes or as a result of habitat loss and other threats. If these populations are below a minimum viable size, they may be subject to inbreeding. and the continued loss of genetic variation by random genetic drift, rather than natural selection. Inbred populations may lose vigour, in terms of reproductive fitness and resistance to disease. The genetic erosion of species is therefore likely to become an increasing problem (Whitmore \& Sayer, 1992). Furthermore, demographic and ecological problems are particularly acute in very small populations.

\section{Ecologically sensitive areas}

The Kanneliya reserve contains areas of greater ecological sensitivity than Dediyagala and Nakiyadeniya, because of its topography (large number of valleys and ridges) and its high stream density. It is important to conserve the Kanneliya reserve in order to protect these ecologically sensitive areas.

Some sites are so sensitive to disturbance that careful consideration is needed as to whether timber should be removed from them. Where there are steep slopes, wet soils, shallow soils, stream banks, and other fragile features, conventional harvesting can cause severe damage. Sometimes the damage is virtually irreparable, and can degrade an ecosystem's productivity for decades or even centuries (Hunter, 1992). 
It is especially sensible to ensure that any relatively undisturbed forests in the riparian zones are protected. Riparian forests are key components in maintaining the biological diversity of the forests. They may be the single most important type of wildlife habitat and by excluding them from harvesting their intrinsic value can casily be maintained. Moreover, they can provide a system of corridors linking all the old-growth stands in a reserve into a network that will mitigate the effects of forest fragmentation (Hunter, 1992).

\section{Prescribed areas for conservation}

The results of the present ecological survey, along with other available data, identify the whole KDN forest complex as a biologically and hydrologically critical area. The Kanneliya reserve can be identified as the core area of the complex on account of its high biodiversity and hydrological importance; it is proposed therefore that it should be made a Totally Protected Area (TPA), with a buffer zone which can be demarcated within the existing boundaries. The southwest and northwest parts of Kanneliya contain major streams (Udugama Dola, Nannikita Ela, Kanneli Ela) which are very important constituents of the catchment of the Gin Ganga. This is the area that is most important for total protection.

An attempt was made to demarcate zones within the complex based on the diversity indices of clusters of plots. However, the index of one cluster of plots (e.g. plots 1-4, 13, 14 , and 21 , or plots $30,34,36-39$, etc.) is not significantly different from another. It is not possible to identify a core area of high diversity representing all three reserves.

The diversity index does not evaluate the habitat diversity or ecosystem diversity. Therefore, it is necessary to rely on other parameters, such as soil conservation and hydrological importance, the total number of plant and animal species in an area, the number of threatened species, the contribution made by endemic species to floristic richness and density (Table 4) and the importance value indices of species, genera and plant families (Tables 13-16), to evaluate a given area for conservation. A comparison of these parameters among the three reserves shows that the Kanneliya reserve is the core area.

It would have been difficult, when conducting field work for a short period (such as two months in the case of the present survey) to carry out detailed sampling of flora, fauna and habitats so as to identify smaller units which have exceptionally high species diversity, habitat diversity, and endemism within the KDN complex. Even if such areas exist it is necessary to protect larger areas in order to conserve ecosystem diversity. Therefore, it is recommended that the whole Kanneliya reserve should be conserved. It is the largest forest reserve ( 5845 ha) in the complex. Dediyagala (3607 ha) and Nakiyadeniya (1694 ha) are accorded lower priority for designation as conservation forests. These two reserves can be managed on a sustainable basis for multiple uses. However, there are a few ridge tops in both Dediyagala and Nakiyadeniya which could be demarcated as protected or conservation areas. 


\section{References}

Bandaranaike. W.M. and Sultanbawa. M.U.S. (1991). A list of the endemic plants of Sri Lanka. Forestry Infortnation Service, Forest Department.

Curtis, J.T. and Mclntosh, R.P. (1950). The interrelations of certain analytical and synthetic phyto-sociological characters. Ecology 32, 434-455.

Dassanayake, M.D. and Fosberg, F.R. (Editors) (1980-) A revised handbook to the flora of Ceylon Vols. I-VII. New Delhi, Amerind Publishing Company.

De Rosayro, R.A. (1942). The soils and ecology of the wet evergreen forests of Ceylon. Tropical Agriculturist 98, 4-14.

Gunatilleke, I.A.U.N and Gunatilleke, C.V.S. (1985). Phytosociology of Sinharaja - a contribution to rain forest conservation in Sri Lanka. Biological Conservation 31, $21-40$.

Gunatilleke. I.A.U.N and Gunatilleke, C.V.S. (1990). Distribution of floristic richness and its conservation in Sri Lanka. Conservation Biologv. 4, 21-31.

Hunter, M.L.Jr. (1992). Wildlife, forests and forestry; principles of managing forests for biological diversity. Prentice Hall.

Mabberley, D.J. (1989). The plant book; a portable dictionary of the higher plants. Cambridge University Press.

NCR (1993). Conservation review of some natural forests in Sri Lanka. IUCN, Sri Lanka. (Prepared for the Food and Agricultural Organization of the United Nations). National Conservation Review.

Nisbet R.H.McD. (1961). A management inventory of the Kanneliya-NakiyadeniyaDediyagala forest area, Cevlon. A Canada-Ceylon Colombo Plan Project.

Wenger, K.F. (1984). Forestry Handbook, 2nd Edition. USA., John Wiley \& Sons.

Whitmore. T.C. and Sayer, J.A. (1992). Tropical deforestation and species extinction. London, IUCN-World Conservation Union/Chapman \& Hall. 